\title{
Love in the Time of Cholera: Latent Love Depictions within a Treatise of Courtly Love
}

\author{
Eliana Garzón-Duarte \\ University of Szeged, Hungary \\ Universidad Distrital Francisco José de Caldas, Colombia \\ eliaga@yahoo.com \\ egarzond@udistrital.edu.co
}

DOI: http://doi.org/10.36892/ijlls.v2i2.232

\begin{tabular}{|c|c|}
\hline $\begin{array}{l}\text { Received: } \\
\text { 25/03/2020 }\end{array}$ & $\begin{array}{l}\text { Abstract } \\
\text { The present article aims at displaying the different types of love bonds implicit }\end{array}$ \\
\hline $\begin{array}{l}\text { Accepted: } \\
\text { 01/05/2020 }\end{array}$ & $\begin{array}{l}\text { in Garcia Márquez's Love in the Time of Cholera. The relationship of } \\
\text { complicity, courting, marriage, wait, and encounter of the lovers are the } \\
\text { expressions through which the author represents latent love manifestations } \\
\text { within the frame of a treatise of courtly love. This article analyzes the realistic }\end{array}$ \\
\hline $\begin{array}{l}\text { Keywords: } \\
\text { García Márquez; } \\
\text { Courtly Love; } \\
\text { Complicity; Courting; } \\
\text { Marriage; Wait; } \\
\text { Encounter }\end{array}$ & $\begin{array}{l}\text { and practical signs of love García Márquez uses to recreate the common } \\
\text { situations any couple can live in a relationship. The common patterns found in } \\
\text { this novel corroborate the unique writing style of the Colombian Nobel Prize of } \\
\text { Literature and the connections with his other novels. The theoretical } \\
\text { approaches of Roland Barthes in A lover's discourse: Fragments and Ovid in } \\
\text { The art of love help construct the basis of interpretation of the love relationships } \\
\text { represented in this novel. Statements of Gurméndez and Charbonneau also } \\
\text { support the concepts of depersonalization and sacrifice inside marriage and the } \\
\text { role memories play in the wait. This article pays attention to three different } \\
\text { couples present in the novel and researches on the type of relationship they } \\
\text { build and the implications and particular conditions they have. All of them with } \\
\text { remarkable features to be studied to understand the realism of love in the words } \\
\text { of García Márquez. }\end{array}$ \\
\hline
\end{tabular}

\section{INTRODUCTION}

Love in the Time of Cholera has been one of the greatest literary works written by Gabriel García Márquez. It is a novel in which a variety of love expressions and relationships are delicately depicted in its prose. The most perceivable topic in this magnificent work is the treatise of courtly love. However, the hidden elements that can be identified in the novel are the ways in which love relationships are expressed in such a treatise. Thereupon, it is inferred that in Love in the Time of Cholera, some stages of love are gently described in the following relationships: (a) Complicity, (b) Courting, (c) Marriage (friendship, depersonalization, infidelity), (d) Wait (memories), and (d) Encounter. These representations of love are theoretically based on approaches of Roland Barthes' A lover's discourse: Fragments, Carlos Gurméndez' Estudios sobre el Amor [Studies on love], Ovid's The Art of Love, and PaulEugène Charbonneau's Amour et Liberté [Love and Freedom], which serve as a horizon for reflections on the love couple.

García Márquez has constructed his unique writing style and populated his characters with stories from people from his hometown in combination with his vast knowledge of readings from different literary periods. That is why, as he tells in his autobiography (2002), the Greek classics were pivotal to build his foundation as a writer: 
What worried him most about me was my dangerous disdain for the Greek and Latin classics, which seemed boring and useless to me, except for The Odyssey, which I had read and reread by chunks several times at the Lyceum. So before saying goodbye, he chose a leather-bound book in the library and gave it to me with some solemnity. "You can become a good writer - he told me- but you will never be very good if you don't know the Greek classics well”. (pp. 394-395)

García Márquez had already used forms of love treatment in his previous works, specifically in the novel that gave him the recognition and success in 1967, but his writing style in order to present the manners of love in Love in the Time of Cholera, makes this novel somewhat superior to One Hundred Years of Solitude (Rodríguez, as cited in Cobo Borda, 1995, p. 240). Rodríguez (1995) affirms that, perhaps, in this work there is not all the imaginative pyrotechnics displayed in One Hundred Years of Solitude, but conversely, more human profundity and slight literary density are present.

Likewise, García Aguilar (1995) assures that in the Colombian literature framework, Love in the Time of Cholera is a time bomb because of the fact that it is a novel full of realism that opens all the traps of the anachronistic structure of the country. The author states that "what in One Hundred Years of Solitude was sweetened, here it is spread with bitterness" (García Aguilar, as cited in Cobo Borda, 1995, p. 250). Moreover, Millán de Benavides (as cited in Cobo Borda, 1995) explains that García Márquez, in his acceptance speech for receiving the Nobel Prize of Literature in 1982, outlined what he would become to develop in his works as a personal project: reinvent love and happiness from the writing. Hence, he started with his cycle of novels Chronicle of a Death Foretold (1981), Love in the Time of Cholera (1985), and Of Love and Other Demons (1994). However, some relationships can be established, not only between these three novels, but also between all the narratives that define the valuable literary work of Gabriel García Márquez.

In the words of Cabello Pino (2010), García Márquez parodies the disease of love in Love in the Time of Cholera (1985), by associating throughout the novel the symptoms caused by love with those of cholera. García Márquez also parodies fidelity between lovers and the pact of love. For this, the romantic hero of the novel, Florentino Ariza, respects his love pact with Fermina Daza, and remains faithful to it for more than fifty years. This is one of the conceptions of the art of courtly love where both the lover and the beloved respect certain codes of behavior, as Capellanus (1990) claims in De amore, the most ennobling love is generally secret and extremely difficult to obtain. This conception of love serves as a means for inspiring Florentino Ariza to keep his pact of love and respect his promises.

\section{Relationship of Complicity}

From the first chapter of this magnificent novel, the reader meets a description of a love story, which main characteristic is the complicity. Such relationship is between two characters that, despite their short appearance, perform an important role in the fantastic storyline and, in the same way, provide a preamble to the great treatise of love. These characters are Jeremiah de Saint-Amour, the Antillean refugee, and the mulatta. This beginning reminds clearly some of the sections of Leaf Storm (1955), because in it, through the monologues of three characters, especially from the one who is an old colonel, the story of a clandestine sentimental life between a suicide doctor and the colonel's family's housemaid is told. Correspondingly, the old doctor, Juvenal Urbino, in vain, turned to the house of a photographer of children, also suicide and foreigner, to play chess and be good as a palliative to the love sorrows from this character with the mulatta.

The relationship between these two characters in Love in the Time of Cholera, can be defined as a relationship of complicity, given that the mulatta assists Jeremiah de Saint-Amour with achieving all his wishes, even death, and hence, as Charbonneau (1982) affirms, it is 
enough to remember that loving someone is to want his happiness, accomplish his desires, and satisfying him with fullness (p. 83). This unique link has canons of fidelity built from its beginning, long ago, in the island of Haiti: "They had met in a convalescent home in Port-auPrince, where she had been born and where he had spent his early years as a fugitive, and she had followed him here a year later for a brief visit, although both of them knew without agreeing to anything that she had come to stay forever" (García Márquez, 1985/1988, p. 13).

From the beginning of the relationship, the mulatta knows the irrevocable decision Jeremiah de Saint-Amour has of ending his life when he was seventy, due to his strong wish to never be old. Despite this background, the love continues and she accepts that brutal determination without the slightest reproach and, worse, keeps it secret as the most precious treasure for the rest of life she shares with him.

The reason that leads her to be an accomplice of something so terrible, according to her own arguments, is the endless love she feels for Jeremiah de Saint-Amour. Her love has transgressed the limits and she prefers not to denounce him, rather than go against his will: "I could not do that -she said, shocked-: I loved him too much" (García Márquez, 1985/1988, p. 14). The mulatta is thus that type of character who is capable of doing anything to attain the happiness of his beloved, even helping him to please his most unknowable wish: never to be old. Roland Barthes (2010) asserts that "I see the other with a double vision: sometimes as object, sometimes as subject; I hesitate between tyranny and oblation. Thus I doom myself to blackmail: if I love the other, I am forced to seek his happiness; but then I can only do myself harm: a trap: I am condemned to be a saint or a monster" (p. 42). The spirit of sacrifice, complicity, the prison of love and its tyranny make love complexity an important axis in the development of the novel.

It is arduous to understand a way of loving as the one from the mulatta because people mostly love in the opposite way. The person who loves cannot wait for spending all the possible time together with their beloved and tries to avoid any detail that might hurt them. Even though the mulatta knew the decision of her beloved, she did not fight for keeping him with her, but conversely, she followed his instructions closely with her peculiar submissive attitude.

Thus, the mulatta is characterized by the devotion and obedience with which she accompanies Jeremiah de Saint-Amour for almost twenty years, until a few hours before the time of his death. She accompanies him in the moments of solitude, happiness and also agony. However, despite sharing many moments together, they prefer to keep their love bond in absolute secret: "She cleaned and straightened the laboratory once a week, but not even the most evil-minded neighbors confused appearance with reality because they, like everyone else, supposed that Jeremiah de Saint-Amour's disability affected more than his capacity to walk" (García Márquez, 1985/1988, p. 14). The fact of maintaining such relationship in secret is another inconceivable decision of Jeremiah de Saint-Amour, in which the mulatta is involved without any resistance, becoming once more his accomplice.

The mulatta accepts Jeremiah de Saint-Amour as he is and with all the conditions that he forces. Gurméndez (1994) explains that knowing the nature of the other, his way of being and behaving, determines an own human love style (p. 75). In the terms of the initial proposal of the present article, this could be titled as complicity, due to the fact that there is a tacit acceptation of the mulatta to the imposed conditions of Jeremiah de Saint-Amour. She is only interested in being happy and she finds this happiness sharing her life with him, even in the hardest situations: "Moreover, a clandestine life shared with a man who was never completely hers, and in which they often knew the sudden explosion of happiness, did not seem to her a condition to be despised. On the contrary: life had shown her that perhaps it was exemplary" (García Márquez, 1985/1988, p. 24). It is evident that her purpose is to achieve all her beloved's wishes, with all her loyalty and from the bottom of her heart, without caring about her own wishes. She stands in the Olympus of love and from there, she decides her fate. This 
defines the dependency as a mechanics of the love vassalage and where one of the couple cedes before the impotence of the feeling.

Thus, it can be inferred that the most remarkable feature in this relationship is the reality both particular characters are living together: adults, free, solitary, with an ignored past, hide a love relation as a pair of kids that are afraid of being found by their parents. In this novel, there is a simple appearance of love complicity between the two characters because behind that love reality there are diverse needs, truths, and fears hidden, which makes love more complicated. They are clandestine lovers that have transgressing the rigidity of norms. Maybe, what Jeremiah de Saint-Amour tries to do when hiding this relationship is to remain it free of judgements, talks, appearance; or maybe, as the quote from Clotilde de Vaux, cited in Barthes (2010): "It is unworthy of great souls to expose to those around them the distress they feel" (p. 42). Consequently, Jeremiah de Saint-Amour prefers to keep this love bond as something that exclusively matters to both.

In sum, García Márquez has recreated the relationship between Jeremiah de Saint-Amour and the mulatta as a clear representation of the complicity they both have interweaved and accepted, in the context of a nineteenth-century society with rigid moral and social values. From the beginning, the mulatta knows the conditions of secrecy that exist beside her beloved one, Jeremiah de Saint-Amour, as she knows his atrocious wish of ending his life when turning seventy years old. She is aware of these circumstances; however, she becomes his accomplice keeping her loyalty in love, with the only purpose of making him happy.

Until this part, it is worthy to highlight that the secret love of these two characters in the first chapter of the novel anchors the further love relationship in the novel, between Florentino Ariza and Fermina Daza. Thus, the first chapter of the novel, although apparently seems to be disconnected from the other chapters, is articulated to the development of the love stories along the novel. Moreover, this affirmation is helpful in the ending of the love between Juvenal and Fermina. He liked to say that their love had been the result of one clinical mistake, while she kept extinguished the fire of love in the servitude of marriage, before she lived the reality of love many years later along with Florentino Ariza. In synthesis, it can be said, by appealing to this novel, that the contradicted types of love determine the essence of complicity.

One thorough reading of the work of García Márquez can give an account on the two types of love he depicts; one, clandestine, terribly censured, that correspond to low, classless, marginal characters; whereas the socially accepted love corresponds to characters of high social position. For example, Amaranta y Pietro Crespi, in One Hundred Years of Solitude; Cayetano Delaura, educated character and the marchioness, Sierva María, in Of Love and Other Demons; and Fermina, with a clean surname, the daughter of a father which has a dark past, and Juvenal, a young doctor, educated in Paris, in Love in the Time of Cholera. The previous statement is to justify that in this novel, the first chapter is a mirror where two attitudes are confronted before love.

Now, another type of love expression in Love in the Time of Cholera is the courting between Florentino Ariza and Fermina Daza. Such courtship is the beginning of a limitless affective bond that, undoubtedly, marks the story along the novel. The look, the letters, the white camellias, and the violin are part of this love courting.

\section{Courting as a Love Expression}

The starting point of the immeasurable love between the characters Florentino Ariza and Fermina Daza is, precisely, a casual look; a look in which all the feelings a human being might cherish are perceived, as it is manifested in the novel: "The lesson was not interrupted, but the girl raised her eyes to see who was passing by the window, and that casual glance was the beginning of a cataclysm of love that still had not ended half a century later" (García Márquez, $1985 / 1988$, p. 39). Both are really young and are living a moment in which love is seen as a 
novel and pleasant feeling; likewise, it is affirmed by Charbonneau (1982) when assuring that youngsters begin to love exactly in the moment of availability and fascination. Therefore, love begins necessarily in the look, since the eyes are the first ones that establish contact with the other being. And it is precisely the look, which enables to delve into the soul of the other in order to try to discover the most secret part of their heart. Gurméndez (1994) affirms that "the eyes contemplate, as faithful mirrors, the object they see. Thus, looking at each other is a recognition to harmonize or deceive each other" (p. 15). The look Fermina offers Florentino makes her remain engraved on his whole being.

Florentino Ariza, then, initiates his discrete life of secret hunter, observing Fermina Daza in her daily comings and goings, meanwhile pretending to read books of verse. This is, perhaps, the first resource he uses to approach Fermina without being so evident: "From seven o'clock in the morning, he sat on the most hidden bench in the little park, pretending to read a book of verse in the shade of the almond trees, until he saw the impossible maiden walk by in her bluestriped uniform) (García Márquez, 1985/1988, p. 40). Therefore, Florentino gives way to the struggle to earn the love of his chosen, as it is stated by Ovid (2012) in the first book of The Art of Love: "In the first place, endeavor to find out an object which you may desire to love, you who are now coming for the first time to engage as a soldier in a new service. The next task after that, is to prevail on the fair by pleasing her. The third is, for her love to prove of long duration" (p. 13). Or also, as it is affirmed by Gurméndez (1994), when he says that to be loved is not an easy task, since it entails to convince and struggle.

After two weeks of constant contemplation, Florentino perceives Fermina as a whole of perfection. He idealizes her and confers some merits that are not yet probable. According to Charbonneau (1982), love is the cause of happiness and always provokes a devoted admiration. Florentino becomes absorbed by Fermina, since he is captivated by her. Therefore, he decides to demonstrate his interest and starts to write her a letter in which he can express all the love that, inexplicably, feels for her. For this reason, he gains inspiration from the lyric books that he has read over and over, while waiting for his beloved to go through the park. Thus, the initial letter becomes a complete treatise of love that is not enough to cherish the immensity of his feelings. Barthes (2010) states that "To try to write love is to confront the muck of language: that region of hysteria where language is both too much and too little, excessive (by the limitless expansion of the ego, by emotive submersion) and impoverished (by the codes on which love diminishes and levels it)" (p. 99).

However, Florentino obeys his mother, Tránsito Ariza, and decides to write a moderate letter for not to terrify Fermina when she receives it. This first letter, apparently simple, has a fairly clear meaning, in which he expresses his most long-awaited wishes: "[...] but then he decided on a sober and explicit half page in which he promised only what was essential: his perfect fidelity and his everlasting love" (García Márquez, 1985/1988, p. 43). These words demonstrate the degree of idealization Florentino had built of Fermina. They were extremely meaningful and serious to be part of the first letter a young guy delivers to an adolescent from whom he only has her unforgettable image.

Likewise, Florentino needs to know what Fermina's feelings are for him to be able to continue with that hope that encourages him to live. Consequently, he waits impatiently to have in his hands a quick reply from his beloved; he needs to receive a minimum sign that makes him believe that all his dreams about her can become true. The love letter is the desire of a rapid answer and the anxiety is the incentive of the sweet suffering that obliges the other one to reply. The uncertainty and the wait make the other person change and assume behaviors that reveal the fire of love in front of others.

From that moment in which Florentino receives the much-desired reply from Fermina, a continuous, almost daily, exchange of messages, in which both give the best of themselves, started. Whereas Florentino discharges his most hidden feelings in his letters, Fermina confines herself to write straightforward excerpts of her daily life for not to fuel any feeling in him. 
Even so, Florentino is pleased to receive his beloved's news, because, as Barthes (2010) assures, it is not necessary to state a clear theme because in reality there is nothing clear to say. The most meaningful is to know that the hands of the beloved will receive the note, in which all the feelings cherished in his whole being are expressed. The fact to know that the letter comes from his beloved, is just a valuable motive to feel her presence next to him.

After two years of continuous messages, Florentino sends a letter to Fermina in which he makes her a formal marriage proposal. When she receives this note, she panics, but thanks to her aunt Escolástica's advice, she answers positively as follows: "Very well, I will marry you if you promise not to make me eat eggplant" (García Márquez, 1985/1988, p. 50). The condition she imposes draws the attention, since, on one hand, it is a quick solution for this inappropriate proposal; and, on the other hand, it accommodates the further feelings of indecision, extension, and prejudice that will make this proposal impossible to come true. Eating eggplants is a clue to understand that forceful disheartening answer that Fermina sends to Florentino when she saw him in the market: "Today, when I saw you, I realized that what is between us is nothing more than an illusion" (García Márquez, 1985/1988, p. 69).

At this point, when analyzing the replies and notes sent back and forth, it can be seen that Love in the Time of Cholera works in a type of symphony in the style of a great orchestration, since once the rejection has been given, with what this chapter of the novel finishes, the next chapter starts with the handsome and seductive figure of Juvenal Urbino to introduce the ideal character that complies the requirements of that high social class love.

Another way Florentino Ariza adopted to win Fermina's heart is sending flowers; namely, white camellias. The letters that Florentino sends to Fermina are closely related to the camellias, considering that several letters go with one of them. The same day that Florentino delivers his first letter, he offers Fermina the camellia he was wearing in the buttonhole, but she rejects it by saying that it is an engagement flower. Over the time of this courting, Fermina does not accept a single white camellia offered by Florentino to avoid, in this way, some kind of serious commitment: "On several occasions during the preceding six months he had sent her a white camellia, but she would return it to him in her next letter so that he would have no doubt that she was disposed to continue writing to him, but without the seriousness of an engagement" (García Márquez, 1985/1988, p. 49).

It is also important to highlight the valuable role that serenades play in the courting between these two characters. Florentino performs serenades coated in love for Fermina. He only needs his violin and the waltz composed for her; without any kind of intermediaries. Thus, the first serenade dedicated to her in the park, takes Fermina by surprise, who quickly discovers that the author of the serenade is Florentino, due to the feeling engraved on each waltz note. Although Florentino decides to play the waltz in a more remote place in order to avoid certain discomforts in Fermina's house, Fermina continues listening to him. This place is the paupers' cemetery, where the sound of music manages to reach an incalculable resonance: "One of his favored spots was the paupers' cemetery, exposed to the sun and the rain on an indigent hill, where turkey buzzards dozed and the music achieved a supernatural resonance" (García Márquez, 1985/1988, p. 49). What really matters to Florentino is not the place where he has to go or whatever he has to do, but the fact of being able to express the immeasurable love he cherishes in his whole being to his beloved, Fermina.

\section{Relationship of Marriage}

Another relationship that can be analyzed in this novel is that of the marriage between Fermina Daza and Juvenal Urbino, which involves various aspects that deserve to be specifically treated, such as friendship, depersonalization, and infidelity. According to Charbonneau (1982), the effort to develop the capacity of admiration for the spouse and the dispossession of oneself are important aspects in the moral of love. 


\section{a. Friendship inside Marriage}

There is, therefore, in the foreground of this marriage the bond of friendship that is considered as a kind of tender, free and selfless love, which helps to affirm marriage. In the case of Love in the Time of Cholera, it can be seen how Fermina Daza in her role as a wife provides a totally selfless help to Juvenal Urbino. She cares for her husband's well-being, for cultivating love in order to grow and be lived in reciprocity: "Ever since their return from their honeymoon, Fermina Daza had chosen her husband's clothes according to the weather and the occasion, and laid them out for him on a chair the night before so they would be ready for him when he came out of the bathroom" (García Márquez, 1985/1988, p. 21).

Love is not a duty because it exists without being able to control it. On the contrary, friendship helps love to grow spontaneously and to find in itself its reason for being. This friendship cannot be placed in a special stage of marriage but must be present from the beginning to the end in order to maintain peace and order inside it. If there is disorder in a marriage, it is because the spouses have not been able to meet. They are injured and, from shock to shock, from disgust to disgust, from protest to protest, an atmosphere of conjugal war is created. Therefore, Fermina continues maintaining a relationship of friendship with her husband, despite her old age, to prevent any sign of compassion that, as Barthes (2010) avers, may be the result of the suffering experienced by the ailments of the other: "So I shall suffer with the other, but without pressure, without losing myself. Such behavior, at once very affective and very controlled, very amorous and very civilized, can be given a name: delicacy: in a sense it is the 'healthy' (artistic) form of compassion)" (p. 58).

In other words, compassion can be effectively disguised by a subtle tactic that allows the other to be helped without demonstrating the suffering that is carried inside. Fermina behaves thusly when she begins to notice the changes that happen to Juvenal with the unforgivable passage of old age. She helps him, but in a clean and selfless way as if she were protecting a child: "After bathing him, Fermina Daza helped him to dress: she sprinkled talcum powder between his legs, she smoothed cocoa butter on his rashes, she helped him put on his undershorts with as much love as if they had been a diaper. And continued dressing him, item by item, from is socks to the knot in his tie with the topaz pin" (García Márquez, 1985/1988, pp. 24-25).

It is also imperative to remark the value of talking in the friendship lived inside a marriage. The spouses get closer and closer with this spirit of mutual communication; the inevitable friction is reduced to smallness, in number and quality. During the fifty years of marriage between Juvenal Urbino and Fermina Daza, there was only one dispute that, despite their triviality, almost led to the breakdown of the relationship: "But one of those trivial games almost ended the first thirty years of their life together, because one day there was no soap in the bathroom" (García Márquez, 1985/1988, p. 22). However, with the friendship they have maintained throughout their married life, they manage to cope with any kind of altercation or difficulty, no matter how simple it may seem.

\section{b. The Role of Depersonalization in Marriage}

Another aspect that is worth dealing with is the depersonalization that Juvenal Urbino suffers next to his wife Fermina. Depersonalization is the fact of leaving the own self to embody another that pleases the partner, thus contributing to the tranquility of the relationship. In this way, Gurméndez (1994) claims that in order to create the love match, love should sacrifice the individual feeling and awareness. And so, a new figure necessarily arises, which, as Hegel affirms, is the virtue of quixotism. Love goes beyond anything that people can even imagine; because it is a promise of happiness, it is also a requirement of perfection or at least spiritual growth. To be loved it is necessary to be kind, to become kind. This is something so obvious 
that, at first glance, it seems trivial, but it is indispensable in the relationship with the other, in the consolidation of the couple.

Within the novel, we can notice how Juvenal Urbino is forced to change certain characteristics of his personality to live in harmony with his wife: "On the eve of old age this physical difficulty inspired Dr. Urbino with the ultimate solution: he urinated sitting down, as she did, which kept the bowl clean and him in a state of grace" (García Márquez, 1985/1988, p. 24). He has to change his behavior, he has to perform acts, often humiliating, for not to contradict Fermina and achieve the coexistence and stability that every marriage needs: "Dr. Urbino tried to convince her, with arguments readily understandable to anyone who wished to understand them, that the mishap was not repeated every day through carelessness on his part, as she insisted, but because of organic reasons" (García Márquez, 1985/1988, p. 24). To love, people sacrifice their self, give themselves to the others, identify with them, forget about themselves and their own essence of being.

Forgetting about oneself is something really difficult, because it can only be done in the way of sacrifice. Consequently, it is necessary to recognize that only this path leads to the salvation of marriage, so that those who prefer the way of ease are condemned to their own love downfall. Gurméndez (1994) asserts that giving oneself cannot be complete without a dispossession of the own being. Obviously, what is given is no longer possessed. Giving oneself, therefore, implies the renunciation of our being to penetrate into the other, to tell him with our actions that we belong to them. These sacrifices of love mean that, in a way, the conjugal relationship is cultivated and enriched. In this generous and reciprocal gift, marriage will find its happiness, which only exists and survives if the inevitable price of depersonalization is paid.

Charbonneau (1982) affirms that marriage is the point of connection between two destinations, two freedoms, two beings, in a new and often definitive unit. In order for this unit of marriage to be carried out and become indissoluble, it is necessary the depersonalization of one of the two parts that comprise it; as in the case of Fermina Daza and Juvenal Urbino, whose marriage manages to last half a century. This long-lasting union is the result of the dispossession of oneself, of sacrifice, of giving in to please the other; because the sacrifice puts in love the seal of eternity. Spouses who know how to give each other feel that their love grows and is fortified to the same extent as their union and they are sure that the time that passes, far from threatening the conjugal bond, increases it. Also, with the passage of time, the reciprocal need increases; Juvenal and Fermina feel closer than ever, because they have built their relationship on rock, so they do not have to doubt their emotional security: "They had just celebrated their golden wedding anniversary, and they were not capable of living for even an instant without the other, or without thinking about the other, and that capacity diminished as their age increased" (García Márquez, 1985/1988, p. 22).

\section{c. Infidelity in Marriage}

Now, another aspect that can be analyzed within the marriage of Fermina and Juvenal is infidelity. This is not deeply marked in the relationship; however, it is worth considering it. It all starts at the moment when Juvenal meets a mulatta, named Barbara Lynch, in the hospital, who was tall, elegant and with the soft nature of molasses. From that first meeting a four-month crisis of clandestine love began. This situation makes happiness in Fermina and Juvenal's marriage jeopardize. The drama of infidelity is an attack against love. Juvenal has fallen into it and runs the risk of killing love with Fermina. This couple, despite their ordinary domestic altercations, traverse for years the path of love with calm and serenity.

Nothing, not even the memory of the love promised by Florentino Ariza, foresees that they can turn away from each other and destroy what they have built with time and dedication. Suddenly, the calm gives way to the storm, the security to the doubt, because Fermina discovers 
that in the clothes of her husband and in the body, there is a smell difficult to describe. It is not of flowers or artificial scents, but something human; Juvenal smells like mulatto. Then the crisis arises and Fermina begins to confirm her fearsome suspicions.

The cause of the infidelity is not precisely the loss of love, but Juvenal's weakness before a woman of incalculable beauty like Barbara Lynch. Juvenal has succumbed to the skilled woman and with an apparent superiority to captivate him. It is enough that fortuitous circumstances throw Juvenal into confusion, and, in the blink of an eye, is involved in an adventure. Although Juvenal is characterized by his moral principles and firmness, he is implicated in this uncontrollable passion in which the supposedly loving adventure leads to purely sexual encounters: "He waited for the afternoons with an unbearable longing, he forgot his other commitments, he forgot everything but her [...]" (García Márquez, 1985/1988, p. 159). There is no time even to speak, only the explosive sexuality of Juvenal prevails, which makes him an easy prey that surrenders to the opportunity of clandestine love affairs. It is a biological infidelity, since Juvenal does not leave his heart with her and rather seems to go back in time to rescue that youth that has strained between his fingers.

After the love encounters there is a mark of moral censorship that determines a strange behavior in Juvenal. He is overwhelmed with the fear of being discovered and then the enormous guilt of having betrayed Fermina: "Then he returned home ashamed of his weakness, longing for death, cursing himself for the lack of courage that kept him from asking Fermina Daza to pull down his trousers and burn his ass on the brazier" (García Márquez, 1985/1988, p. 160). It is the voice of conscience and the voice of the conjugal commitment that overcome the temptation that had begun four months ago. Undoubtedly, the marriage relationship between Juvenal and Fermina handle the difficult situations of the love life. Affective stability, complicity, the strength of habits do not allow marriage to disintegrate and, instead, generate a timely solution to the problem: mutual commiseration, gloomy tenderness, and forgiveness.

\section{The Wait Alive through Memories}

Cabello Pino (2015) explains that the first thing readers can perceive from Love in the Time of Cholera is the 'quixotic' nature of Florentino Ariza's character. Florentino believes himself a character in a love novel and, therefore, also behaves as such. He acts unreasonably in anything that has to do with the love he feels for his beloved, Fermina Daza, especially the long wait for being with her. This reminds us of Don Quixote's wild nature in everything about chivalry. Florentino Ariza is characterized as the exaggeration of a romantic hero who is able to die in the name of love, when fighting, for example, with Fermina's father: "Shoot me, he said, with his hand on his chest- "There is no greater glory than to die for love" (García Márquez, 1985/1988, p. 56). This heroism is one of the love topics coming from the GrecoLatin classical tradition (Moreno Soldevila, 2011), among others implicit in the novel. Florentino believes that the excess of the lovers in love novels are worthy of admiration. Therefore, he tries to imitate them to win the love of his beloved: the intense love letters he writes to Fermina, his determination of playing the waltz he composed for her, and his decision of respecting 'in his own way' his oath of eternal fidelity and love forever during more than fifty years despite of her abandonment.

He has passed through various bodies, but only adheres to the illusion that Fermina will ever accept him. Many times he has tried to approach her, but it has been impossible. She marries, while he sinks in pain and sorrow. From that disastrous moment in his life, he promises that he will wait for her. He thinks that Juvenal has to die sooner or later. It is a long wait, cruel, but justified to his purposes. He looks into other paths and discover that he must gain prestige and popularity to deserve Fermina. This is how he makes commitments with his uncle Leon XII to expand the shipping company. It is a matter of honor rather than a merchant spirit. Florentino realizes that his beloved is not far, nor elusive or distant. He is patient. He knows 
how to wait. That is why he is conscious and able to overcome the obstacles of time to win the heart of his beloved:

If she's not charming or courteous enough, at your loving, endure it and persist: she'll soon be kinder. You can get a curved branch to bend on the tree by patience: you'll break it, if you try out your full strength. With patience you can cross the water: you'll not conquer the river by sailing against the flow. (Ovid, 2012, p. 29)

In this long stage of waiting, Florentino tries to fill the hole that Fermina leaves in his heart. For this reason, he seeks innumerable occasional loves to satisfy his repressed desires. These loves pass through and cannot be compared to the love he has for Fermina Daza, since he considers that she is definitely irreplaceable: "Fifty years later, when Fermina Daza was freed from her sacramental sentence, he had some twenty-five notebooks, with six hundred twenty-two entries of long-term liaisons, apart from the countless fleeting adventures that did not even deserve a charitable note" (García Márquez, 1985/1988, p. 101).

Carlos Gurméndez (1994) explains this aspect, using the terms of absolute love and relative love. He ensures that absolute love is the definitive need of another being to be able to live, while relative loves are temporary and only give moments of pleasure. This is Florentino's love for Fermina: absolute, eternal, sincere, loyal. Fidelity should not be conceived as belonging exclusively to the order of the sexual. Being faithful to the other is, first of all, reserving the heart for the loved one, in the same way that Florentino did throughout his life. True love follows only one path in search of happiness, while sexual desire runs in different paths, in search of any unknown object that provides satisfaction. Gurméndez (1994) claims that "love demands and awaits eternity, while passion burns and blazes in itself" (p. 83). Florentino recognizes that waiting is dangerous; however, he is sure to hope that Fermina will be at his side sooner or later to make him happy.

Also, it is necessary to analyze that, during the waiting time, another important aspect is developed in the novel: the memories. This is the happy or heartbreaking remembrance of the loved one in her gestures, her words and everything that surrounds that beloved. Florentino Ariza lives suspended in the memory of his beloved. From the moment she rejects him, Florentino does not stop thinking about her for a single moment and lives ephemeral loves to mitigate her absence. He knows that he cannot be next to her, but he must keep the burning flame of love through the living memories and believes that he maintains that fervor in the moment he imagines hearing Fermina Daza's voice.

Florentino's love adventures do not allow him to overcome the memories, because on the contrary, they become a hoax. For him, the only woman who deserves all kinds of idealization is her beloved Fermina. As Ovid (2012) describes, the great pleasure of love is the challenge of winning the heart of the beloved with all the struggle needed: "But why fail, when there's pleasure in new delights and the more foreign the more they capture the heart? The seed's often more fertile in foreign fields, and a neighbor's herd always has richer milk" (p. 13). Love is an act of possession and the memory, to Florentino, is to be immersed in time and in the evocation of happiness and possession of Fermina: she is the owner and the reason of his life. There is a large number of similarities between Ovid and Gabriel García Márquez's depictions of love, as Robinson (2013) explains, that cannot seem to be much further apart in the way they represent the reality of love.

\section{The Encounter of the Lovers}

The cycle of the love relationship depicted along the novel closes with the encounter of the lovers. True love, without false illusions, does not march down the path of escape to new fantasies. It is a reality and constitutes a perpetual struggle. Thus, Florentino waits half a century for the event that leads him to the definitive encounter with Fermina to take place: the death of Juvenal Urbino. That long 
wait has its reward the night Florentino, dressed in mourning, with his hand on his chest and with the trembling voice of love, says to Fermina: "I have waited for this opportunity for more than half a century, to repeat to you once again my vow of eternal fidelity and everlasting love" (García Márquez, $1985 / 1988$, p. 37). Despite what is thought about the eternity of love, the encounter of this couple is the clearest vocation of the romantic; where absolute love means the vital need of that unique creature that is mired in loneliness and anguish, as Fermina is in the transit of her first widowhood night.

This statement by Florentino, as a sign of his Homeric struggle, finds the success or reward of that constant and stormy confrontation against old age. It is a struggle with time and with death in the name of love and in it the eternal commitments are assumed by the heart. Here, a new stage in the life of Florentino and Fermina begins. It is as if they had met in love in the most intense intimacy and that from this new encounter, they began to live a new love relationship. This occurs at the moment when Florentino reiterates to Fermina the oath of fidelity and eternal love from half a century ago, and reminds her of the series of encounters, letters, conversations, looks in the course of that clandestine love life.

This phase of the novel allows a direct relationship with the fourth chapter of Chronicle of a Death Foretold (1981), in which Angela Vicario really falls in love with Bayardo San Román. That love grounded on letters has its result twenty-three years later, when she was embroidering with her friends and Bayardo shows up one afternoon with the certainty of love in his eyes. Both, despite their old age, feel the disturbance of love, which without asking permission, has been reborn in them.

In this way, after an unbroken connection, Florentino and Fermina embark on the journey of love along the Magdalena River, where they can relive the tenderness, the most sublime moments of happiness, the grace of looks and the madness of love. The joy, the pleasure, and the fulfillment of the promises work in the encounter and the union of the lovers, in that coming and going by the river, as a metaphor of the transit of love through time. According to Cabello Pino (2018), this journey along the Magdalena River supports the topic of navigium amoris, when situating the characters on a trip that is clearly a unique and exclusively trip of love and for love.

Lovers have already broken the barricades of social and cultural morals; they have already reclaimed the adventure of love; it only remains to enjoy the long time that old age holds for them. Maybe, a lifetime for older people over eighty is not long, but what they have left to live will be loving each other and they cannot longer conceive of loving themselves other than sailing aboard this boat (Cabello Pino, 2018, p. 34). The Captain of the boat asks Florentino about how long he thinks they can keep this coming and going: "Florentino Ariza had kept his answer ready for fifty-three years, seven months, and eleven days and nights" (García Márquez, 1985/1988, p. 225). And, likewise in No One Writes to the Colonel (1961), this novel of love ends with a sharp and masterful phrase: "Forever".

\section{CONCLUSION}

Love in the Time of Cholera is a majestic love story in which real depictions of love are described with the unique writing style of García Márquez. It is not a common novel, but it is more understood as a love treatise that can be linked to any other medieval treatise of courtly love. Therefore, this article brings love topics depicted in the love treatises as The Art of Love, De amore, and A Lover's Discourse, which come from the Greco-Latin classical tradition. Love is understood here as an act of freedom, not easy to achieve. All the love stories intertwined in this novel lead to the learning of love as a culmination of a lifetime, that it is not closed or limited, but open to imagination, memories, and decisions. The novel tells throughout its pages the process that the two main characters, Florentino Ariza and Fermina Daza, follow during their lives to gather those essential experiences necessary to truly understand, appreciate and enjoy love. 
As this story narrates real scenarios of love, moments of happiness and bitterness can be identified and perceived by readers. Florentino and Fermina wait all their lives to be happily together. However, the way García Márquez leads the story involves the reader in the pleasure and art of love by experiencing moments apparently humorous, but full of reality. Although different topics of love are implied and treated in this novel, mainly when referring to Florentino and Fermina, this article displayed those love bonds that are latent in other couples of the novel as well. For this purpose, the Antillean refugee Jeremiah de Saint-Amour and the mulatta were the couple that introduced this treatise of love depicting a relationship based on complicity. Dr. Juvenal Urbino and his wife, Fermina Daza, were the great characters who unfold the life inside marriage, describing relations of friendship, infidelity, and depersonalization. The relationship between Florentino and Fermina was studied in this article from the perspective of love courting, lifelong wait, and encounter of the lovers.

\section{REFERENCES}

Barthes, R. (2010). Lover's discourse: Fragments. (R. Howard, Trans.). New York, NY: Farrar, Straus and Giroux. (Original work published 1978).

Cabello Pino, M. (2010). Motivos y tópicos amatorios clásicos en El amor en los tiempos del cólera [Classic love motives and topics in Love in the time of cholera]. Huelva: Servicio de Publicaciones de la Universidad de Huelva.

(2015). El influjo cervantino en El amor en los tiempos del cólera [The influence of Cervantes in Love in the time of cholera]. La Palabra, 26(1), 47-58.

(2018). El tópico del navigium amoris en El amor en los tiempos del cólera: de Propercio y Ovidio a Gabriel García Márquez [The topic of navigium amoris in Love in the time of cholera: from Propercio and Ovid to Gabriel García Márquez]. In Paola Bellomi, Claudio Castro Filho, and Elisa Sartor (Eds.), Desplazamientos de la tradición clásica enlas culturas hispánicas (pp. 19-37). Coimbra: Imprensa da Universidade de Coimbra.

Capellanus, A. (1990). The art of courtly love. (Translated with an introduction by John Jay Parry). New York, NY: Columbia University Press. (Original work known De amore)

Cobo Borda, J. G. (1995). Repertorio crítico sobre Gabriel García Márquez [Critical repertoire about Gabriel García Márquez]. Bogotá: Instituto Caro y Cuervo.

Charbonneau, P. E. (1982). Amor y libertad [Love and Freedom]. Barcelona: Herder.

García Márquez, G. (1955). La Hojarasca [Leaf Storm] (1st ed.). Bogotá: Ediciones SLB.

(1961). El Coronel no tiene quien le escriba [No One writes to the colonel]. Medellín: Aguirre Editor.

(1981). Crónica de una muerte anunciada [Chronicle of a Death Foretold]. Bogotá: Editorial Oveja Negra.

(1985). El amor en los tiempos del cólera (1st ed.). Bogotá: Editorial Oveja Negra.

(1988). Love in the time of cholera. (E. Grossman, Trans.). New York, NY: Alfred A.

Knopf. (Original work published 1985).

(2002). Vivir para contarla [Living to tell the tale]. Bogotá: Editorial Norma.

Gurméndez, C. (1994). Estudios sobre el amor [Studies on love]. Barcelona: Anthropos Editorial.

Moreno Soldevila, R. (ed.) (2011). Diccionario de motivos amatorios en la literatura latina (siglos

III a. C. - II d. C.) [Dictionary of love motifs in Latin literature (III century BC - AD II)].

Huelva: Universidad de Huelva (Exemplaria Clássica). 
Ovid (2012). The art of love. London, UK: Vintage, Random House.

Robinson, L. (2013). Gabriel García Márquez and Ovid: Magical and Monstruous Realities. London, UK: Boydell \& Brewer.

\section{$\underline{A U T H O R^{\prime} S B I O}$}

Eliana Garzón-Duarte is a doctoral candidate of English Applied Linguistics at University of Szeged, in Hungary, as a scholarship holder from the Stipendium Hungaricum program. She holds an M.A. in Language Teaching from Universidad Pedagógica y Tecnológica de Colombia. She is a full-time teacher of the Faculty of Education at Universidad Distrital Francisco José de Caldas. Her research interests are identity construction, language education, linguistic diversity, and literature. 